\title{
Gas Production, Gas Flaring And Economic Growth Nexus: The Nigerian Experience
}

\author{
Salami Dada Kareem ${ }^{1}$;Daskareem VeraEnoho ${ }^{1}$ Oladipo Kolapo Sakiru ${ }^{2}$ \\ ${ }^{1}$ Contacts: Department of Economics, Faculty of Social Sciences, Lagos State University, \\ Ojo, Lagos, Nigeria; \\ ${ }^{2}$ Contacts: Department of Human Resource Development, Universiti Putra Malaysia.
}

\begin{abstract}
Gas flaring has been condemned by scholars and the international community due to its contribution to climate change thereby posing hazards to the environment and its resources. This Paper corroborates this submission by revealing an adverse effect of gas flaring on economic growth of Nigeria. While gas flaring did not help the economy to grow, gas production and population did. Capital formation in its lagsfollowed suit with gas flaring. Thus, if the total stoppage of gas flaring is achieved urgently, it can serve as one way of salvaging the economy from poor growth.
\end{abstract}

Keywords: Economic growth, Gas flaring, Gas production, Nigeria,

\section{Introduction}

Energy is at the core of human existence and also the pillar of wealth creation. As such, modern society cannot seriously address issues of development without effective energy planning and management that will enhance optimal utilization, regular supply and availability of energy resources. Components of economic forecasts and performance are oil and gas, which are crucial to the contemporary global economy with their prices. Whether measured by volume or value, crude oil, natural gas and refined petroleum products constitute the largest single item internationally(1). Thus, in national, regional and global economiesoil and gas are strategic resources.

Both as a source of energy and as a feedstock for industrial natural gas is rapidly gaining more importance. This growth is being driven by a number of factors including: an abundant resource base which makes up the supply side of the economy; growing energy demand from an expanding world economy constituting the demand side; environmental pressures for the use of gas which is a relative "clean" fuel in comparison to oil or coal; improved technologies for the production, transportation and conversion of natural gas. Thus, most economies of the world are now diversifying away from oil to gas as an energy source (2).

Nigeria ranked $8^{\text {th }}$ in the world in terms of proven reserves and the largest in Africa (3).This huge gas reserve has remained largely untapped since the ascendancy of crude oil as the nation's major cash earner. In fact, petroleum experts regard Nigeria "as a gas province with little oil" (4). Nigeria's proved reserves of natural gas were estimated at 184 trillion cubic feet (TCF) in 2008 (5). In Nigeria, natural gas is obtainable in two main forms, which are associated with natural gas (AG) and non-associated natural gas (Non-AG). However, many of the gas fields discovered (or non-associated gas) was incidentally discovered in the course of searching for oil. Several of such fields remained largely unappraised or abandoned (3).

The onshore activities centered mainly in the Niger Delta area where massive wealth is being generated for the nation. Unfortunately, the oil industry has created serious health and environmental pollution problems for the host communities largely through gas flaring and oil spillage. The environmental impacts of these activities have been of concern to government regulatory agencies, oil companies' operators as well as the host communities. No wonder why gas flaring has reduced from $46.21 \%$ of total gas produced in 2003 to $24.30 \%$ in 2010 (6). Yet, concerned parties have not shown adequate commitments and sincerity towards having robust environmental preservation and cleaning-up. Various control programs and policies that are articulated by government for the mitigation of the environmental hazards have not been sincerely implemented.Violent protests by communities are the most eloquent testimonies of the resistance to the general pollution of the environment by the activities of the oil companies. The government's amnesty and post-amnesty programs since 2010 have helped to calm down the area.

This study is practically germane towards management of the Nigerian project because of scarcity of similar studies in the literature.The following section provides the methodology and theoretical framework. This is followed by the presentation and discussion findings. The conclusion was drawn in the last section. 


\section{A. Data Collection}

\section{Materials And Methods}

The data obtained was mainly from secondary sources including the Central Bank of Nigeria Statistical Bulletin where data on values of output (real GDP) and capital stock (K) measured by gross capital formation were obtained,the National Bureau of Statistics, where the data on labor stock (L) measured in terms of populationandgas production (GP) as well as gas flared (GF) were obtained from Nigerian National Petroleum Commission technical records. Carbon (iv) oxide $\left(\mathrm{CO}_{2}\right)$ released to the environment due to gas flaring was computed from the GF values using Avogadro's law. All the data covered 1970- 2008 period. The data was tested for stationarity or the order of integration of the data series in order to eliminate spurious regression results. This test used the augmented Dickey-Fuller (ADF) and Phillips Perron (PP) Approaches. A pairwise correlation test was also conducted on the explanatory variables to test for the possibility of perfect collinearity between and among the variables so as to eliminate affected variable(s) from the regression analysis.

\section{B. Theoretical Framework and Model Specification}

The neoclassical Cobb-Douglass production function provides the theoretical framework.The aggregate production function follows:

$\mathrm{GDP}_{\mathrm{t}}=\mathrm{A}_{\mathrm{t}} \mathrm{K}_{\mathrm{t}}^{\alpha} \mathrm{L}_{\mathrm{t}}^{\beta}$

Where:

$\mathrm{GDP}_{\mathrm{t}}$ is the aggregate production of the economy at time $\mathrm{t}$; At, Kt and $\mathrm{L}_{\mathrm{t}}$ denote the Total Factor Productivity (TFP), capital stock and labour stock at time t respectively. Other factors such as gasproduction (GP), gas flare (GF) and volume of carbon (iv) oxide $\left(\mathrm{CO}_{2}\right)$ released from gas flares are assumed to be exogenously determined, which represented the TFP in this case. Therefore, the TFP is specified as:

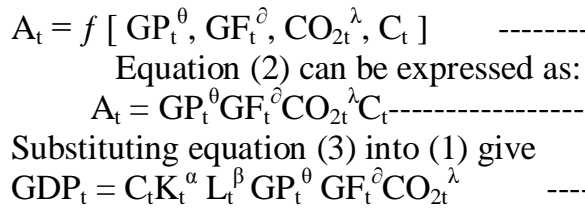

To estimate equation (4), we take the logarithm of the right side of the equation. This is shown in equation (5)

$\mathrm{GDP}_{\mathrm{t}}=\mathrm{C}_{\mathrm{t}}+\alpha \log \mathrm{K}_{\mathrm{t}}+\beta \log \mathrm{L}_{\mathrm{t}}+\theta \log \mathrm{GP}_{\mathrm{t}}+\partial \log \mathrm{GF}_{\mathrm{t}}+\lambda \log \mathrm{CO}_{2 \mathrm{t}}+\mu_{\mathrm{t}}$

Where:

$\mathrm{C}_{\mathrm{t}}=$ constant parameter

$\mu_{\mathrm{t}}=$ the error term

$\mathrm{GDP}_{\mathrm{t}}$, remains as earlier defined, $\log \mathrm{K}_{\mathrm{t}}, \log \mathrm{L}_{\mathrm{t}}, \mathrm{InGP}_{\mathrm{t}}, \log \mathrm{GF}_{\mathrm{t}}$ and $\log \mathrm{CO}_{2 \mathrm{t}}$ are logarithms of the variables as defined above.

The terms $\alpha, \beta, \theta, \partial$, and $\lambda$ are coefficients of the parameters of $\mathrm{K}_{\mathrm{t}}, \mathrm{L}_{\mathrm{t}}, \mathrm{GP}_{\mathrm{t}}, \mathrm{GF}_{\mathrm{t}}$ and $\mathrm{CO}_{2 \mathrm{t}}$ respectively.

This multivariate co-integration approach was adopted to test the long-run relationship or equilibrium convergence in the variables.

\section{A priori Expectations}

It was expected that $\alpha>0 ; \beta>0 ; \theta>0 ; \partial<0 ; \lambda<0$. That is, all the coefficients other than that of GF and $\mathrm{CO}_{2}$ were expected to be positive.

\section{A. Stationary Test}

\section{Discussion Of Results}

In applying the augmented Dickey-Fuller (ADF) test to the variables, $\log \mathrm{L}_{\mathrm{t}}, \log \mathrm{GF}_{\mathrm{t}}$, and $\log \mathrm{CO}_{2 \mathrm{t}}$ were found to be stationary at levels at $5 \%$ significance level. The approximate critical values at $1 \%$ and $5 \%$ levels were -3.6 and -2.9 respectively. However, the ADF test statistic of $\mathrm{GDP}_{\mathrm{t}}, \log \mathrm{K}_{\mathrm{t}}$ and $\log \mathrm{GP}_{\mathrm{t}}$ were less than the critical value at $1 \%$ and $5 \%$, respectively, and hence not stationary after the first differencing. This is indicated in table 1.1. The Phillips-Perron (PP) test in table 1.2 shows similar results except that $\log \mathrm{L}_{\mathrm{t}}, \log \mathrm{GF}_{\mathrm{t}}$, and $\log \mathrm{CO}_{2 \mathrm{t}}$ were stationary at levels at both $1 \%$ and $5 \%$ significance level. Aside the model specification based on the theoretical framework, the explanatory variables were logged to remove the possibility of having variables that may not be integrated after many times of differencing. When such variables are logged before performing econometric tests, they are made to follow a linear trend and are integrated (7). Our findings confirmed this position. For 
instance, population adopted to represent labour force is known not to be integrated after many periods of differencing but its logarithm was integrated at level in this analysis.

Table 1.1: Augmented Dickey-Fuller Unit Root Test of Variables

\begin{tabular}{|l|l|l|}
\hline Variables & Levels & First Difference \\
\hline $\mathrm{GDP}_{\mathrm{t}}$ & $1.388723^{*}$ & $-5.421698^{* * * *}$ \\
\hline $\log \mathrm{K}_{\mathrm{t}}$ & $-0.595778^{* *}$ & $-5.769672^{* * *}$ \\
\hline $\log \mathrm{L}_{\mathrm{t}}$ & $-3.189855^{* *}$ & \\
\hline $\log \mathrm{GP}_{\mathrm{t}}$ & $-2.014525^{* *}$ & $-7.279027^{* * * *}$ \\
\hline $\log \mathrm{GF}_{\mathrm{t}}$ & $-3.589609^{* *}$ & \\
\hline $\log \mathrm{CO}_{2 \mathrm{t}}$ & $-3.589609^{* *}$ & \\
\hline
\end{tabular}

Approximately, the ADF critical values at $1 \%$ and 5\% are -3.6 and -2.9 accordingly.

Not stationary $\left(^{*}\right)$ Stationary at $5 \%$ level $\left({ }^{* *}\right)$ Stationary at $1 \%$ level $\left({ }^{* * * *}\right)$

Source: Authors' Computation

Table 1.2: Phillips-Perron Unit Root Test of Variables

\begin{tabular}{|l|l|l|}
\hline Variables & Levels & First Difference \\
\hline $\mathrm{GDP}_{\mathrm{t}}$ & $1.608709^{*}$ & $-5.419496^{* * * *}$ \\
\hline $\log \mathrm{K}_{\mathrm{t}}$ & $-0.595778^{*}$ & $-5.769672^{* * * *}$ \\
\hline $\log \mathrm{L}_{\mathrm{t}}$ & $-5.860383^{* * *}$ & \\
\hline $\log \mathrm{GP}_{\mathrm{t}}$ & $-1.998121^{*}$ & $-7.709618^{* * * *}$ \\
\hline $\log \mathrm{GF}_{\mathrm{t}}$ & $-3.630092^{* * * *}$ & \\
\hline $\log \mathrm{CO}_{2 \mathrm{t}}$ & $-3.630092^{* * * *}$ & \\
\hline
\end{tabular}

Approximately, the PP critical values at $1 \%$ and 5\% are -3.6 and -2.9 accordingly.

Not stationary $\left(^{*}\right) \quad$ Stationary at $5 \%$ level $\left(^{* *}\right)$ Stationary at $1 \%$ level $\left({ }^{* * *}\right)$

Source: Authors' Computation

\section{B. Multicollinearity Test}

The pair-wise correlation of the predictors of the model in table 1.3 showed that there was perfect collinearity between $\log \mathrm{GF}_{\mathrm{t}}$ and $\log \mathrm{CO}_{2 \mathrm{t}}$, thus the need for elimination of one of the two variables from the model to avoid multicollinearity problem. So, $\log \mathrm{CO}_{2 \mathrm{t}}$ was eliminated since $\mathrm{CO}_{2}$ was computed from the gas flared.

Table 1.3: Pair-wise Correlation Test Results

\begin{tabular}{|c|c|c|c|c|c|}
\hline & $\log \mathrm{K}_{\mathrm{t}}$ & $\log L_{t}$ & $\log \mathrm{GP}_{\mathrm{t}}$ & $\log \mathrm{GF}_{\mathrm{t}}$ & $\log \mathrm{CO}_{2}$ \\
\hline $\log K_{t}$ & 1.00 & 0.91 & 0.88 & 0.56 & 0.56 \\
\hline $\log L_{t}$ & 0.91 & 1.00 & 0.86 & 0.45 & 0.45 \\
\hline $\log \mathrm{GP}_{\mathrm{t}}$ & 0.88 & 0.86 & 1.00 & 0.76 & 0.76 \\
\hline $\log \mathrm{GF}_{\mathrm{t}}$ & 0.59 & 0.45 & 0.76 & 1.00 & 1.00 \\
\hline $\log \mathrm{CO}_{2 \mathrm{t}}$ & 0.56 & 0.45 & 0.76 & 1.00 & 1.00 \\
\hline
\end{tabular}

Source: Authors' Computation

\section{Cointegration Test}

Gas production, gas flared and economic growth, among other variables would proceed in an error correction mechanism if there is an evidence of cointegrating equations (CEs) or vectors. The Johansen cointegration multivariate test in table 1.3 has shown no long-run relationship in the model as revealed by both the maximum Eigen value and Trace tests. Therefore, the model is paramount explained by short-run movements in the variables.

\section{4: Johansen Cointegration Test Results}

\begin{tabular}{llllll}
\hline $\begin{array}{l}\text { Hypothesized No. } \\
\text { of CEs }\end{array}$ & $\begin{array}{l}\text { Max. Eigen Value } \\
\text { Statistic }\end{array}$ & $\begin{array}{l}\text { Max. } \\
\text { Critical Vigen } \\
\text { 5\% level }\end{array}$ & $\begin{array}{l}\text { Trace } \\
\text { Statistic }\end{array}$ & Test & $\begin{array}{l}\text { Trace } \\
\text { Critical Value }\end{array}$ \\
\hline None & 31.26440 & 33.88 & 60.45703 & 69.82 \\
At most 1 & 15.29720 & 27.58 & 29.19263 & 47.86 \\
At most 2 & 7.912403 & 21.13 & 13.89543 & 29.80
\end{tabular}




\begin{tabular}{lllll} 
At most 3 & 4.538919 & 14.26 & 5.983027 & 15.49 \\
At most 4 & 1.444108 & 3.84 & 1.444108 & 3.84 \\
\hline
\end{tabular}

Source: Authors' Computation

\section{Regression Outcomes}

The regression coefficients of the model in table 1.5 were all in agreement with our a-priori expectations except that of capital formation. The model in its static state was well fit and positive autocorrelation was not suggested. An increase in capital formation in the current years would reduce economic growth in Nigeria. However, this empirical evidence was not statistically significant at 5\% level. But the evidence became statistically significant at 5\% level over the lagged periods (see table 1.6-1.9 in appendix) and the significance level rose with increase in the lag of the variable (capital formation) without reducing the overall significance of the model.

Table 1.5: The Regression Model in its Static State

Dependent Variable: GDP,

Method: Least Squares

\begin{tabular}{lccc}
\hline \multicolumn{1}{c}{ Variable } & Coefficient & t-Statistic & t-Statistic \\
\hline C & -1717967 & -6.503519 & 0.0000 \\
Log K & -25935.53 & -1.564152 & 0.1270 \\
Log L & 1005222 & 7.314959 & 0.0000 \\
Log GP & 554215.3 & 6.405713 & 0.0000 \\
Log GF & -554686.4 & -7.895710 & 0.0000 \\
\hline R-squared & 0.967090 & & \\
Adjusted R-squared & 0.963219 & & \\
F-statistic & 249.7835 & & \\
Durbin-Watson & 1.546403 & & \\
Prob(F-statistic) & 0.000000 & & \\
P70 2008; Include & & &
\end{tabular}

Sample: 1970 2008; Included observations: 39

Economic growth rises with an increase in the population of Nigerians. A similar trend was found for gas production. Unfortunately, the rate of growth of Nigeria's economy had been reduced by the volume of gas flaring. All the evidences were statistically significant at all levels.

\section{Concluding Remarks}

The focus of this paper was to examine the nexus among gas production, gas flaring and Nigeria's economic growth. Capital formation and population, however, constituted the intervening variables. Given the negative impact of gas flaring and the lags of capital formation on the growth of the emerging economy, the policy of complete eradication of gas flaring and revitalization of the electricity sector should be at the Frontline. Besides, the evidence of short-run movements of the variables provides pertinent baseline information for policy makers to progressively diversify the economy. The action time should not be tomorrow but now. Failure to move the economy from a mono state to a multidimensional one is prepared for doom in the nearest future. There is an urgent need for the government to provide an environment that is conducive for investment in the gas industry as this will lead to additional income to both the people and government of Nigeria.

\section{References}

[1] Stephens, P. (2005). Promoting economic development through the oil and gas sector. Paper Presented to the Royal Institute for International Affairs, London.

[2] Barnes H. (2005). National gas and geopolitics from 1970 to 2040.htt://www.cambridge.org/catalogue/catabogue.asp Adenikinju, A. (2010). Developing Nigeria's domestic gas industry: The role of appropriate pricing. In Energy, Environment and Economic Growth. Proceedings of the 2010 NAEE Conference, Abuja, Nigeria.

[3] Gaius-Obaseki, J.E. (1996). Potential for African sub-regional gas market.NAPETCOR, $4^{\text {th }}$ Quarter Odoni Global Resources (2009).Nigerian gas master plan implementation review. Draft Report Submitted to DPR, Lagos.

[4] NNPC (2010).Annual Statistical Bulletin.First Edition.

[5] Asteriou, D. and S.G. Hall (2007).Applied Econometrics.Revised Edition. Palgrave Macmillan 